\title{
Small mammals of the Dalat Plateau, southern Vietnam
}

\author{
Alexei V. Abramov, Sergei V. Kruskop \& Anton V. Shchinov
}

\begin{abstract}
Field surveys within the Bi Doup - Nui Ba National Park located in north-east part of the Dalat Plateau (Lam Dong Province, southern Vietnam), from 2002 to 2009, have allowed us to document the local presence of 36 species of small mammals. These include one tree shrew (Tupaiidae), one mole (Talpidae), three shrews (Soricidae), two roundleaf bats (Hipposideridae), two horseshoe bats (Rhinolophidae), eight evening bats (Vespertilionidae), one bent-winged bat (Miniopteridae), six squirrels (Sciuridae), ten mice and rats (Muridae), one bamboo rat (Spalacidae) and one porcupine (Hystricidae). Thus, though because of climatic features the bat fauna is relatively deplete, the Dalat Plateau on the whole has one of the most diverse mammalian faunas in southern Vietnam.
\end{abstract}

KEY WORDS: mammals, Dalat Plateau, Bi Doup - Nui Ba National Park, Vietnam.

AlexeiV.Abramov [a.abramov@mail.ru], Zoological Institute, Russian Academy of Sciences, Universitetskaya nab. 1, Saint Petersburg 199034, Russia; Sergei V. Kruskop [kruskop@zmmu.msu.ru], Zoological Museum, Moscow State University, ul. Bolshaya Nikitskaya 6, Moscow 125009, Russia; Anton V. Shchinov [schinov_anton@mail.ru], Joint Vietnam-Russian Tropical Research and Technological Centre, Nguyen Van Huyen, Nghia Do, Cau Giay, Hanoi, Vietnam.

\section{Мелкие млекопитающие Далатского плато, южный Вьетнам}

\section{А.В. Абрамов, С.В. Крускоп, А.В. Щинов}

РЕЗЮМЕ. Исследования в национальном парке Бидуп-Нуйба, расположенном в северо-восточной части Далатского плато (провинция Ламдонг, южный Вьетнам) в 2002-2009 гг. позволили установить обитание 36 видов мелких млекопитающих. Список млекопитающих включает тупайю (Tupaiidae), крота (Talpidae), трех землероек-белозубок (Soricidae), двух листоносов (Hipposideridae), двух подковоносов (Rhinolophidae), восемь видов гладконосых летучих мышей (Vespertilionidae), длиннокрыла (Miniopteridae), шесть видов белок (Sciuridae), десять видов мышей и крыс (Muridae), бамбуковую крысу (Spalacidae) и дикобраза (Hystricidae). Таким образом, хотя, в связи с климатическими особенностями исследованной территории, ее фауна рукокрылых обеднена, в целом Далатское плато характеризуется одной из наиболее разнообразных фаун млекопитающих в южном Вьетнаме.

КЛЮЧЕВЫЕ СЛОВА: млекопитающие, Далатское плато, национальный парк Бидуп-Нуйба, Вьетнам.

\section{Introduction}

The Dalat Plateau located at the southern end of the Annamite (Truong Son) Mountain Range. Located mainly in the Central Highlands province Lam Dong, the Dalat Plateau is a mountainous, and $70 \%$ of its area is covered in forest. Several of the mountains in this area rise to over 2,000 $\mathrm{m}$, the highest being the Chu Yang Sin Mountain $(2,442 \mathrm{~m})$ at the north. Two other high points are the $\mathrm{Bi}$ Doup Mountain in the east, which reaches 2,287 $\mathrm{m}$, and the Lang Bian Mountain, a 2,167 $\mathrm{m}$ peak in the south (Fig. 1).

Few protected areas established at the Dalat Plateau largest being the Bi Doup - Nui Ba National Park at the northeast. This national park ranks among the five largest national parks in Vietnam, covering 64,800 ha of forest. According to biologists, the Bi Doup - Nui Ba National Park is home to the oldest primordial forest in the Central Highlands.
This area attracts attention of biologists at all times. Since the beginning of 20th century zoological expeditions worked in the Dalat Plateau (see Rozhnov, 1998 for the review). Many species and subspecies of widely distributed Indochinese mammals were firstly described from this region (Bonhote, 1907; Elliot, 1909; Thomas, 1909; Robinson \& Kloss, 1922; Miller, 1940). Mentioned the unique zoogeographical position of the discussing region, one can suppose here the presence of the mammalian fauna comprising species of Indo-Burmese and Malayan origin. First could invade the Plateau through the Annamite mountainous ridges, the latter should come from the foothills. Very probable that distribution of Indo-Burmese species on the Plateau should be of relic type represented by partial or full isolates from the main distribution areas.

Few biodiversity surveys in northeast part of the Dalat Plateau were carried out in 2002-2009 by the Joint Vietnam-Russian Tropical Research and Techno- 


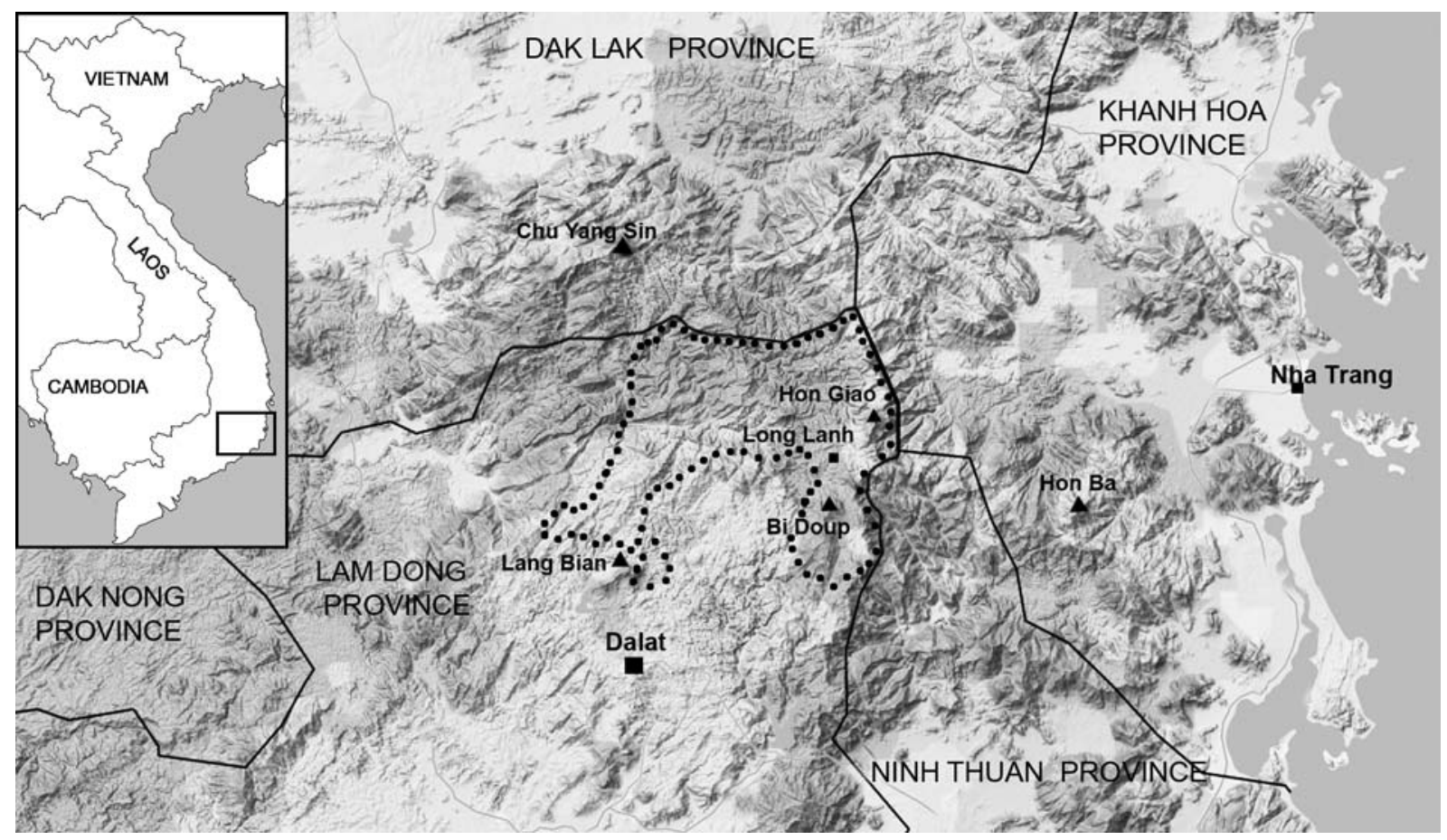

Figure 1. Map of the Dalat Plateau, southern Vietnam. The location of the Bi Doup - Nui Ba National Park is shown.

logical Centre. In this paper, we summarize the results of wildlife surveys in the Bi Doup - Nui Ba National Park hitherto unexplored in respect to mammalogy, with special attention to species occurrence and their ecological peculiarities.

\section{Material and methods}

Fieldworks were conducted from 2 April to 26 April in 2002, 26 March to 24 April in 2008 and from 29 April to 9 May in 2009. In 2002 the base camp was located near Long Lanh Village $\left(12^{\circ} 10^{\prime} \mathrm{N}, 108^{\circ} 39^{\prime} \mathrm{E}\right)$. In 2008 and 2009 the main base camp was situated on the right bank of Danim River, $5 \mathrm{~km}$ northeast of Long Lanh Village, Lam Dong Province $\left(12^{\circ} 10^{\prime} 44^{\prime \prime} \mathrm{N}, 108^{\circ}\right.$ $40^{\prime} 44^{\prime \prime} \mathrm{E}$ ), at the elevation of $1400 \mathrm{~m}$ a.s.l. Main forest types occurring in the radius of $1-3 \mathrm{~km}$ of the base camps the study site were surveyed, with an altitudinal range of 1400-2050 $\mathrm{m}$ a.s.l. being covered (Figs. 2-3). Additional surveys were conducted on the northern slope of the Bi Doup Mountain (elevation 1700-2100 $\mathrm{m}$ a.s.l.) and on the southern slope of the Hon Giao Mount, at the elevation $1850 \mathrm{~m}$ a.s.1.).

Different types of traps were used as follows: (1) large $(11 \times 11 \times 25 \mathrm{~cm})$ cage live-traps, each with a bait of a foam-rubber piece saturated with vegetable oil to be replaced every 2-3 days; (2) pitfall traps, i.e. plastic baskets and glasses of different sizes ( $40 \mathrm{~cm}$ deep and $30 \mathrm{~cm}$ in diameter, $18 \times 20,14 \times 15$, and $13 \times 9 \mathrm{~cm})$, buried flush with the ground surface. We also use the special tunnel mole-traps in 2009.
In total of 750 trap-nights in 2002, 527 trap-nights in 2008 and 700 trap-nights in 2009 were conducted for the live-traps. The pitfall traps were set up for 60 trapnights in 2002, 3006 trap-nights in 2008 and 2050 trapnights in 2009.

Bat observations were conducted visually with the help of electric lanterns, and acoustically by the use of narrow-band heterodyne ultrasound detector D100 (Pettersson Elektronik AB, Sweden). Taking into account local weather conditions resulted into bat activity pattern timed mainly to evening hours, most observations were held in the thirst half of night time, from the sunset till the $21^{30}-22^{30}$. For capturing alive bats standard technique of crossing bat flying paths by the nylon mistnets (size $7 \times 2$ and $10 \times 4 \mathrm{~m}$ ) was used (Kunz \& Kurta, 1990; Borissenko \& Kruskop, 2003) together with the hand net or flap-trap (Borissenko, 1999). In total number of worked observing and trapping nights in 2002, 2008 and 2009 was counted 24, 28 and 14, respectively.

The standard external body measurements (head and body length, tail length, hind foot length, ear length) were taken. For bats, the forearm and tibia lengths were also measured. Weight was taken in grams. Voucher specimens of each species (except squirrels) were taken for confirmation of the record and further comparison with museum collections because of impossibility of clear identification of most species in the field. Except for voucher specimens, all trapped mammals were released. Voucher specimens were cataloged and studied at the Zoological Institute Russian Academy of Sciences (ZIN, Saint-Petersburg, Russia) and Zoological Museum, Moscow State University (ZMMU, Moscow, 


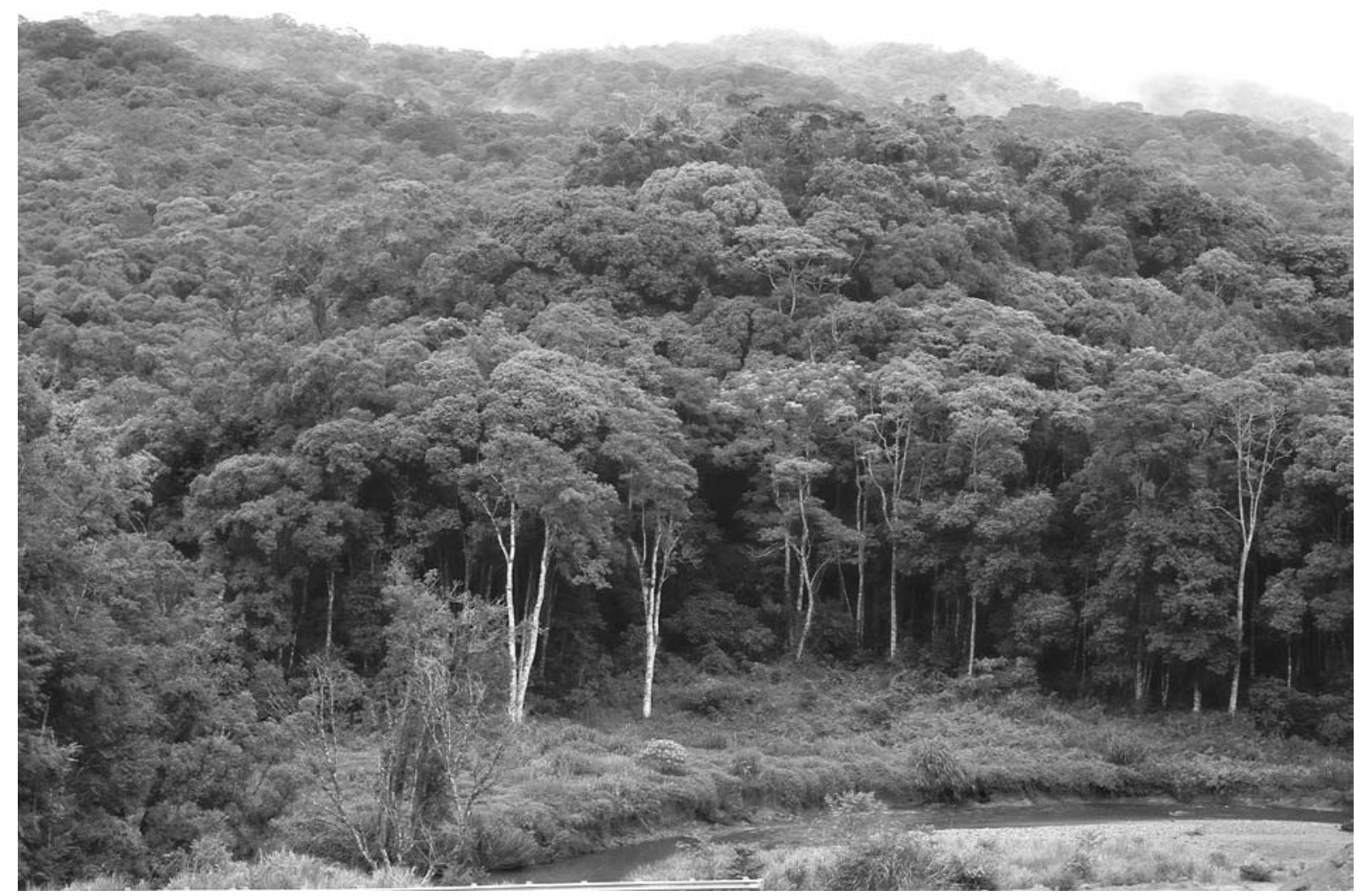

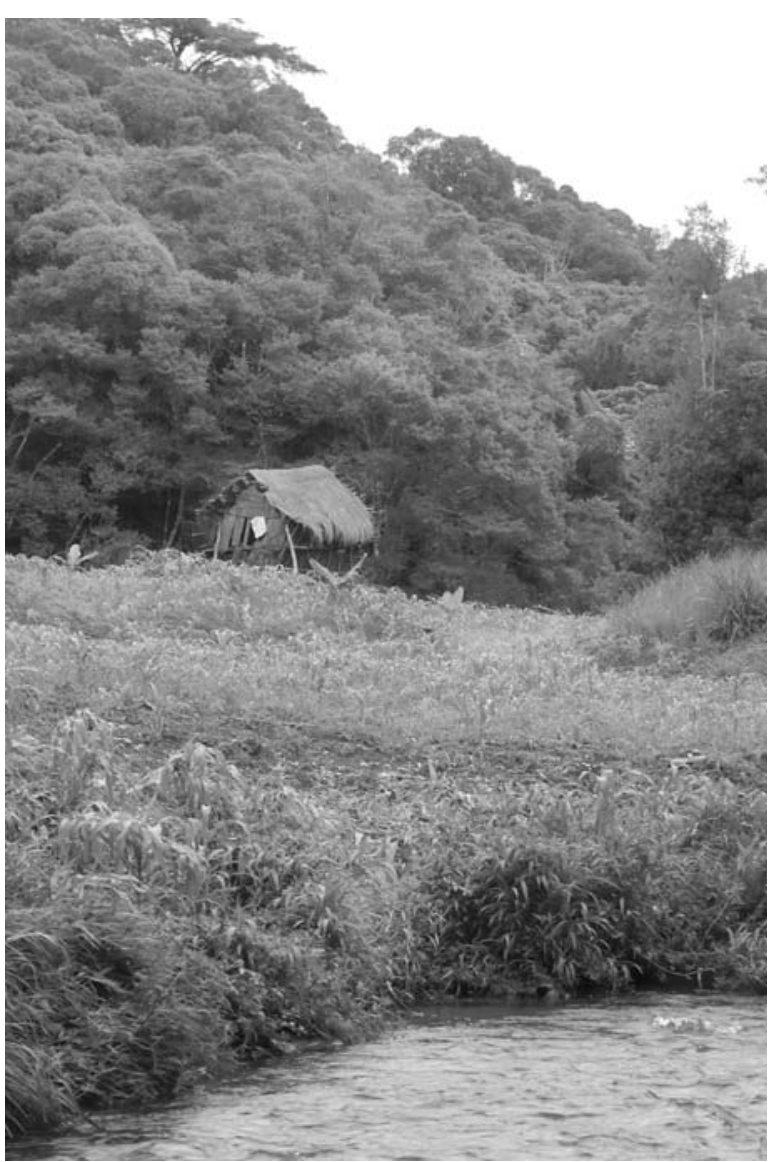

Figure 2. Hilly landscape surrounding the Danim River valley. Evergreen subtropical forest, covering the hills, represents habitat for Niviventer spp., Chiropodomys gliroides, Tamiops maritimus, Rhinolophus affinis; river valley and forest edges represent foraging biotopes of Pipistrellus coromandra, Scotomanes ornatus and Myotis spp.

Russia). Most specimens were preserved in $75 \%$ ethanol. Tissue samples for genetic studies were taken from fresh specimens or from wing membranes of alive bats and stored in $96 \%$ ethanol.

\section{Results}

We report 36 species of small mammals (bats, insectivores and rodents) from the Dalat Plateau based on visual records and 310 trapped specimens. The following accounts provide descriptions of species and relevant taxonomic notes along with natural history information for each species collected. The nomenclature of mammals used here follows Wilson \& Reeder (2005) unless otherwise stated.

Figure 3. Cornfield in the river curve, surrounded by evergreen forest; foraging station for Myotis horsfieldii, M. phanluongi and Pipistrellus coromandra. 


\section{ORDER SCANDENTIA}

Family TUPAIIDAE

Tupaia belangeri (Wagner, 1841)

The northern treeshrew is common species in Vietnam distributed in many provinces (Dang Ngoc Can et al., 2008). We observed two animals at 21 April 2004 near Danim River in 5-6 km from Long Lanh Village. This species was not recorded during the surveys in 2008 and 2009.

\section{ORDER SORICOMORPHA}

Family SORICIDAE

Crocidura attenuata Milne-Edwards, 1872

A widespread and common Southeast Asian species known throughout Vietnam (Hutterer, 2005; Dang Ngoc Can et al., 2008).

Common species in the studied area. We collected 42 specimens during three field surveys. Specimens of C. attenuata were collected between $1350 \mathrm{~m}$ and 1850 $\mathrm{m}$ a.s.1. The Asian gray shrews were found in different biotopes - open grasslands, corn fields, disturbed mixed forest, mossy forest and primary forest. C. attenuata were caught in most of pitfall lines - near the base camps of 2002 and 2008-2009, along the Danim River, on slope of the Bi Doup Mountain (up to $1800 \mathrm{~m}$ a.s.l.) and on the southern slope of the Hon Giao Mount (up to $1850 \mathrm{~m}$ a.s.l.).

Crocidura indochinensis Robinson et Kloss, 1922

The species was described from the Lang Bian Mountain at the south part of the Dalat Plateau (Robinson \& Kloss, 1922). This species was regarded as a subspecies of Crocidura horsfieldii (Jenkins, 1976; Heaney \& Timm, 1983; Jiang \& Hoffmann, 2001). It was recognized as a distinct species by Van Peenen $e t$ al. (1969), Hutterer (2005), and Jenkins et al. (2009). On biogeographic grounds $C$. horsfieldii is thought to be restricted to Sri Lanka and peninsular India (Lunde et al., 2003).

Crocidura indochinensis is poorly represented in museum collections. From museum records, this species has an apparently disjunct distribution (see Jenkins et al., 2009). In Vietnam the species found in northern provinces (Lao Cai and Vinh Phuc) and Lam Dong Province (Dang Ngoc Can et al., 2008; Jenkins et al., 2009). Specimens from the Lang Bian Mountain formerly considered by Heaney \& Timm (1983) to belong to $C$. indochinensis were identified as $C$. rapax by Jenkins et al. (2009).

We collected 8 specimens in 2008, no specimens were collected in 2002 and 2009. This species is a smallest in number among Bi Doup' shrews, in 2008 it consists only $11.6 \%$ of shrew catches. All specimens of C. indochinensis were collected at the elevation 1400 $\mathrm{m}$, in pitfalls located in the tall grasslands near the base camp.

\section{Crocidura sp.}

The most abundant shrew in 2008-2009 was a small (head and body length $48-57 \mathrm{~mm}$ ), gray shrew with a relatively long tail, ranging from $59-70 \%$ of head and body length. We collected 39 specimens in 2008 and 14 specimens in 2009.

The taxonomic status of this form is still unclear. It is comparable in size to the other four small shrews, $C$. kegoensis, C. zaitsevi, C. annamitensis, and C. guy known in Vietnam (Jenkins et al., 2009). This form is distinguished from these species by a combination of characters. It has a longer tail relative to head and body length than that of $C$. kegoensis $(56 \%)$ and $C$. annamitensis (56-61\%), shorter than that of C. guy (68$77 \%$ ). The body size and relative length of tail of $\mathrm{Bu}$ Doup form is similar to that of $C$. zaitsevi (tail length 61-81\%), the species recently described from Ngoc Linh Mount in Kon Tum Province, Central Highlands (Jenkins et al., 2007).

\section{Family TALPIDAE}

Euroscaptor parvidens (Miller, 1940)

There are presumably three Euroscaptor species in Vietnam (Dang Ngoc Can et al., 2008), morphological difference between which is not clear. Populations from the Dalat Plateau supposed to belong to the species $E$. parvidens. This species was described from the "agricultural station Blao" (= Bao Loc) in the southern part of the Plateau (Miller, 1940).

During the survey of 2002, numerous mole life marks were observed in the Bi Doup foothills and on the fields along Danim River (Borissenko et al., 2006), but only single specimen was captured on the send shore of Danim River. In 2008 and 2009 numerous traces of mole activity (old and fresh mounds and channels) were observed on cornfield nearby the base camp (Fig. 4) and on the on the send shore of Danim River. Four adult males were captured by the mole-traps near the base camp.

\section{ORDER CHIROPTERA}

\section{Family HIPPOSIDERIDAE}

Hipposideros armiger (Hodgson, 1835)

This bat species is widely distributed throughout southern Asia and occurs in many regions of Vietnam (Corbet \& Hill, 1992; Borissenko \& Kruskop, 2003; Dang Ngoc Can et al., 2008), inhabiting wide variety of biotopes.

The only one individual (adult male) was captured while foraging along the forest edge at the elevation of ca. $1400 \mathrm{~m}$ a.s.l. Probably this species represents rare vagrant on the Dalat Plateau or occurs there seasonally.

\section{Coelops frithii Blyth, 1848}

This bat has relatively wide but highly sporadic distributed in Southeast and Eastern Asia (Corbet \& Hill, 1992). Its natural history seems to be very poorly known.

One adult male was captured in 2009 (Fig. 5). At least two animals were observed in the late evening flying (probably foraging) over the backwater, very close to water surface, and one of them was caught by the flap-trap. Previously it was supposed that Coelops 


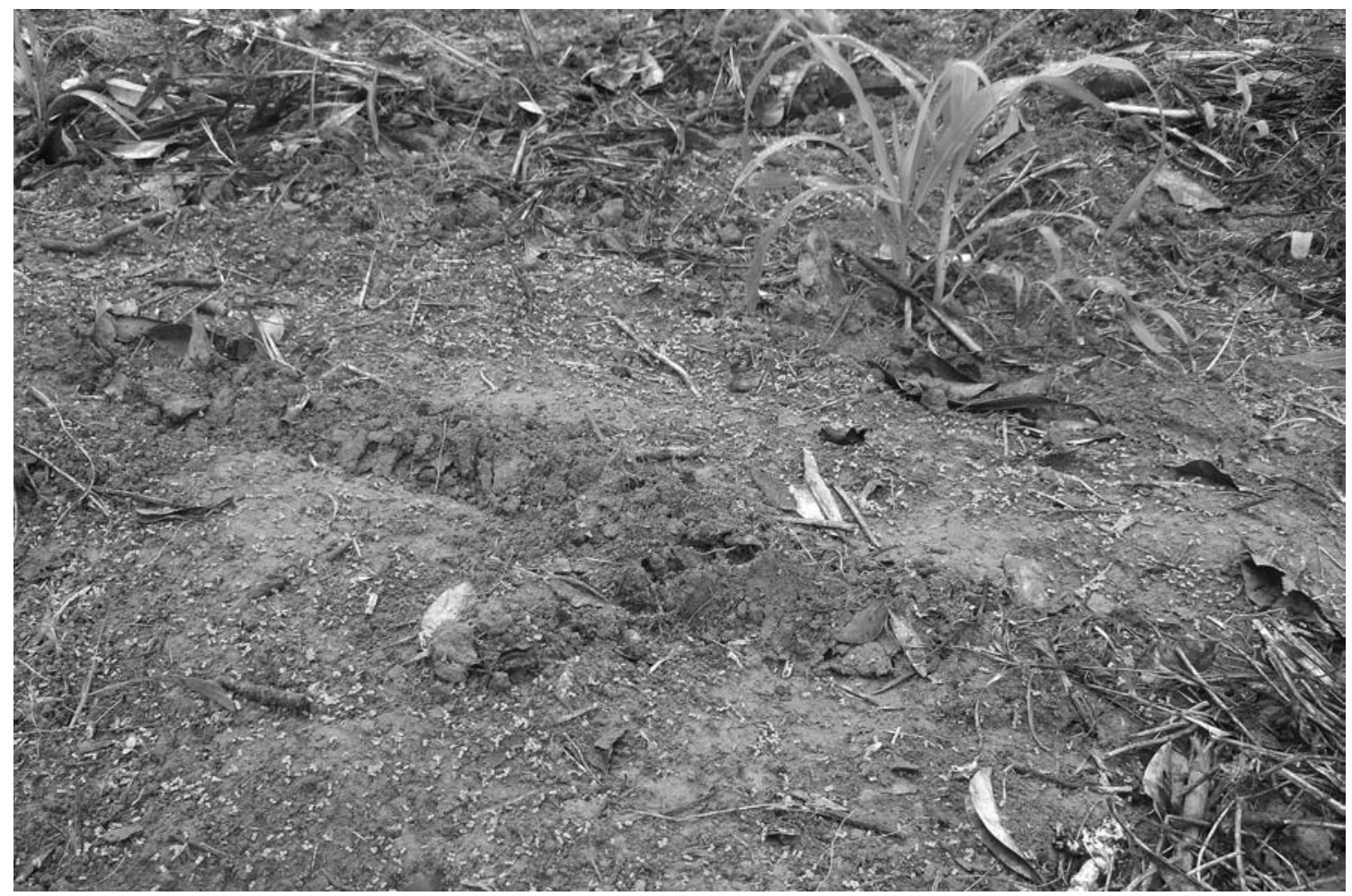

Figure 4. Channel of small-toothed mole Euroscaptor parvidens on the cornfield.

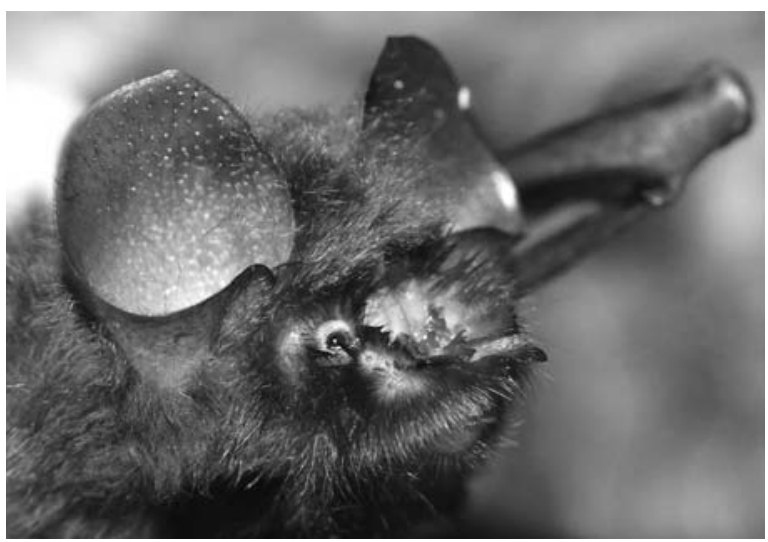

Figure 5. Funnel-eared leaf-nosed bat Coelops frithii, male.

hunts in grassy vegetation level, a few centimeters above the ground (Borissenko et al., 2001). Dang Ngoc Can et al. (2008) does not report that species for Southern Vietnam; however it was already known from the Cat Tien National Park, Dong Nai Province (Borissenko \& Kruskop, 2003). Thus our record from Danim River is the second one for the Southern Vietnam and the first for the Dalat Plateau.

\section{Family RHINOLOPHIDAE}

Rhinolophus affinis Horsfield, 1823

This horseshoe bat is widely distributed in southern Asia and occurs in many regions of Vietnam (Corbet \& Hill, 1992; Csorba et al., 2003; Dang Ngoc Can et al.,
2008), supposedly inhabiting various mountainous forests (Borissenko \& Kruskop, 2003).

The species should be one of the most common and abundant bat species in the northern part of the Dalat Plateau. It was previously reported from this territory on the basis of ten individuals captured in primary forest on the Bi Doup Mountain at the elevation of ca. $1800 \mathrm{~m}$ a.s.l. (Borissenko et al., 2006). Six individuals were captured in 2008 and seven in 2009. Also these large horseshoe bats with relatively fast flight and CF echolocating signal at about $76 \mathrm{kHz}$ were numerously observed in the investigated area, foraging along the riverside growth as well as inside the forest between tree trunks. In 2002 mainly adult males and only two not breading females were captured. However in 20082009 number of males and females amongst captured horseshoe bats was nearly equal. One female in 2008 and two females in 2009 were lactating, marking April as breading time for this species.

Rhinolophus cf. lepidus Blyth, 1844

This bat species is widely distributed trough southern Asia (Corbet \& Hill, 1992; Csorba et al., 2003) and sporadically occurs in regions of Vietnam (Dang Ngoc Can et al., 2008). Its difference from closely related $R h$. pusillus is not clear (Borissenko \& Kruskop, 2003) and hence some of localities of the latter species may probably belong to $R h$. lepidus and vice versa.

Four individuals were captured in 2008. These animals were essentially identical to specimens from the Mount Hon Ba identified as Rh. pusillus (Borissenko et 
al., 2006). However, according to relatively large size (forearm length 38.1-41.8 $\mathrm{mm}$; tooth row length in one specimen $6.32 \mathrm{~mm}$ ) and broadly acute connecting process they are better resemble $R h$. lepidus. On the other hand, shape of the lancet (not abruptly narrowed in distal third) of all the captured specimens looks more common to Rh. pusillus (Csorba et al., 2003). Similar size horseshoe bats were observed several times in various forest habitats including relatively high cluttered places at elevations $1400-1900 \mathrm{~m}$ a.s.1. in 2002 and 2008. Foraging behavior is similar to that of $R h$. affinis, however $R h$. lepidus has more maneuverable flight and thus can use more cluttered space. We did not observe any perching behavior; both horseshoe bats were seen hunting by only aerial hawking. In two captured females large embryos could be easily palpated, which mark end of April as breading season for this species.

\section{Family VESPERTILIONIDAE}

Myotis muricola (Gray, 1846)

This mouse-eared bat is one of the most widely distributed and common Southern Asian insect bats (Corbet \& Hill, 1992; Borissenko \& Kruskop, 2003), inhabiting high variety of biotopes almost throughout Vietnam (Dang Ngoc Can et al., 2008). However, there is high probability that this bat actually represents a complex of forms on questionable rank a needs a deep taxonomic reassessment. Specimens from the Dalat Plateau morphologically and, according to preliminary data, genetically are similar to that from lowlands of Southern Vietnam.

This species was reported from the investigated area on the base of six animals captured in 2002 (Borissenko et al., 2006). One adult female was captured on Danim River in 2008, one adult male was captured near the Danim River tributary in 2009. According to survey of 2002, M. muricola was common along the Danim River valley, multiply observed in different biotopes including anthropogenic changed stations. Contrary, during the surveys of 2008-2009, this species was uncommon in the investigated area and recorded by very few observations. All the captures and observations of M. muricola in the investigated area were made in the river valleys, usually over the stream or nearby it. However their foraging behavior was not connected with water; animals usually hunted hawking along the vegetation, about $1.5-5 \mathrm{~m}$ from the ground or water surface.

Myotis horsfieldii (Temminck, 1840)

This Myotis species is widely distributed throughout southern Asia (Corbet \& Hill, 1992); however its known distribution in Vietnam is highly sporadic (Bates et al., 1999; Borissenko \& Kruskop, 2003; Dang Ngoc Can et al., 2008). It is traditionally thought that this form is connected in its distribution with valleys of large rivers.

For the first time this bat was captured on the Dalat Plateau in 2002 over the Danim River nearby the $\mathrm{Bi}$

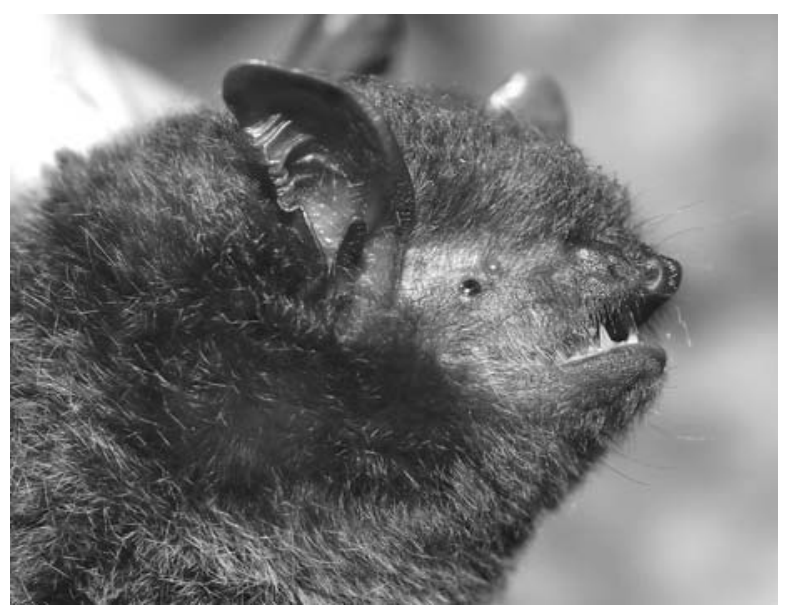

Figure 6. Horsfield's myotis Myotis horsfieldii, adult male.

Doup foothills (Borissenko et al., 2006). We did not either capture or observe this species in 2008, however two specimens (adult and subadult males) were caught on the Danim River tributary in 2009 (Fig. 6). Despite opinion that $M$. horsfieldii is specialized trawler, animals foraged in the manner typical to that of M. murico$l a$, flying over the river and riverine biotopes at about 2$6 \mathrm{~m}$ above land. 2009

Myotis phanluongi Borisenko, Kruskop et Ivanova,

This small Myotis was recently described from the Mount Hon Ba located in Khanh Hoa Province, $30 \mathrm{~km}$ westward of the Bi Doup Mountain (Borisenko et al., 2009). This form closely related to more widely distributed M. siligorensis, supposed to replace the latter species on the elevations over $1300 \mathrm{~m}$ a.s.l.

One individual (adult female) was captured over the Danim River shore in 2008, representing the only documented record of the species out of the Hon Ba Mount. Animals of supposedly same species we observed multiple times in 2008-2009. Bats hunted over river, usually very close to water surface, emitting the steep FM very silent echolocation signals with maximum energy at about $42-45 \mathrm{kHz}$.

Pipistrellus coromandra (Gray, 1838)

This bat species is widely distributed throughout southern Asia (Corbet \& Hill, 1992), having also wide but sporadic distribution in Vietnam (Borissenko \& Kruskop, 2003; Dang Ngoc Can et al., 2008). Some Indochinese records may be resulted from misidentification of $P$. tenuis.

On the Dalat Plateau this species is one of most common and numerous bats, inhabiting different types of forest and foraging along forest edges, creeks, ravines, over corn fields and clearings in the manner typical to pipistrelles (e.g. Kalko, 1995). In $2002 P$. coromandra were found on different elevations and were abundant even on the Bi Doup Mountain at elevation of ca. $1700 \mathrm{~m}$ a.s.l. (Borissenko et al., 2006). Ten 


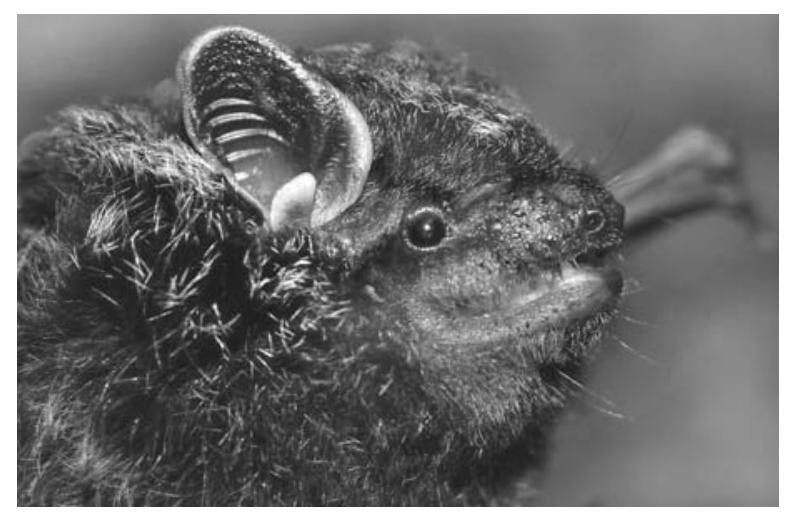

Figure 7. Black gilded serotine Arielulus circumdatus, adult male.

individuals were captured in 2008 and eight in 2009 in the foraging stations of the species. All individuals captured in 2002 and 2008 were full growth males, but in 2009 two subadult females were also caught.

Arielulus circumdatus (Temminck, 1840)

This remarkable bat has highly sporadic distribution throughout southern Asia including Vietnam (Corbet \& Hill, 1992; Borissenko \& Kruskop, 2003; Dang Ngoc Can et al., 2008). Knowledge of its natural history is limited. There is possibility that there are more than one species in the complex since Vietnamese bats possess some visible difference from Nepalese specimens preserving in ZMMU.

One adult male was captured on the Bi Doup Mountain in 2002, three males and one female were caught in the Danim River valley in 2008, and one male was captured over the stream in 2009 (Fig. 7). Arielulus seems to be quite common in the investigated area. We multiply observed these bats during all the three surveys. Animals demonstrate fast but relatively maneuverable flight while hawking along the forest edges and above the cornfields at about 4-15 $\mathrm{m}$ above land. Foraging usually began just after the sunset, at $18^{05}$. Echolocation calls loud shallow FM with maximum energy at 35-40 kHz. Faeces of the animals captured in 2008 contained fragments of thick bright chitin indicating presence of large beetles of the genus Anomala in the Arielulus diet.

\section{Scotomanes ornatus (Blyth, 1851)}

This bat has wide distributed in tropical Asia including Vietnam (Corbet \& Hill, 1992; Dang Huy Huynh et al., 1994; Borissenko \& Kruskop, 2003; Dang Ngoc Can et al., 2008), inhabiting mainly mountainous forests.

Two males and female were captured in 2008. According to our observations, this species should be rather common in the investigated area, using the same foraging stations as Arielulus. We observed foraging Scotomanes multiply but most observations were made during survey of 2008. Foraging flight is fast and not very maneuverable. Animals usually took their prey in the air, at about $10-20 \mathrm{~m}$ above land some times coming down to 3-5 m. However once we observed Scotomanes taking some insects from leafs on the edge of tree canopy. Echolocation calls loud shallow FM with maximum energy at $30-32 \mathrm{kHz}$.

Previously Scotomanes was not known from Vietnam south of Gia Lai Province (Hendrichsen et al., 2001). Thus we recorded it from the Dalat Plateau and from the Southern Vietnam on the whole for the first time.

Murina harpioloides Kruskop et Eger, 2008

This tiny tube-nosed bat was recently described from the Dalat Plateau (Kruskop \& Eger, 2008). This species supposed to be endemic of the northern part of the Dalat Plateau and probably neighboring mountains, inhabiting primary mountainous forests. The holotype of the species (adult female) was originated from the Bi Doup Mountain. One specimen (young male) was captured in the valley of small forest creek in 2008. Taking into account age of this individual, possessing cartilaginous incretions in wing phalanges, $M$. harpioloides could produce offsprings in January or February, during the dry season.

Previously this species was misidentified as $M$. aurata (Borissenko \& Kruskop, 2003; Borissenko et al., 2006).

Harpiocephalus harpia (Temminck, 1840)

This remarkable bat is widely but sporadically distributed throughout southern Asia including Vietnam (Corbet \& Hill, 1992; Dang Huy Huynh et al., 1994; Borissenko \& Kruskop, 2003; Dang Ngoc Can et al., 2008). Knowledge of its natural history is very limited.

One adult male was captured in partly destroyed and now self repairing mountainous forest in 2008 (Fig. 8). Animal was caught into the mist net set over the surface of a forest creek. There is still discussed problem of presence in Vietnam of two morphotypes of Harpiocephalus, which sometimes are treated as separate species, $H$. harpia s.str. and H. mordax (e.g. Dang Ngoc Can et al., 2008). However, the latter larger form is known by females only, thus there strong arguments supporting by certain genetic data that the two forms represent just a case of high sexual dimorphism (Matveev, 2005). Our specimen looks somewhat intermediate between the two morphotypes, having forearm length of $50 \mathrm{~mm}$, which is exceed size of all known Harpiocephalus males.

\section{Family MINIOPTERIDAE}

Miniopterus magnater Sanborn, 1931

This bat, sporadically distributed throughout Southeast Asia and Oceania (Corbet \& Hill, 1992), is known from only three localities in Vietnam (Borissenko \& Kruskop, 2003; Dang Ngoc Can et al., 2008).

Remains of the single specimen of large bent-winged bat (forearm length $48.7 \mathrm{~mm}$, length of the upper tooth row $6.82 \mathrm{~mm}$ ) were found as roadkill about $4 \mathrm{~km}$ northwest from the Hon Giao Mount in 2009. Traditionally 


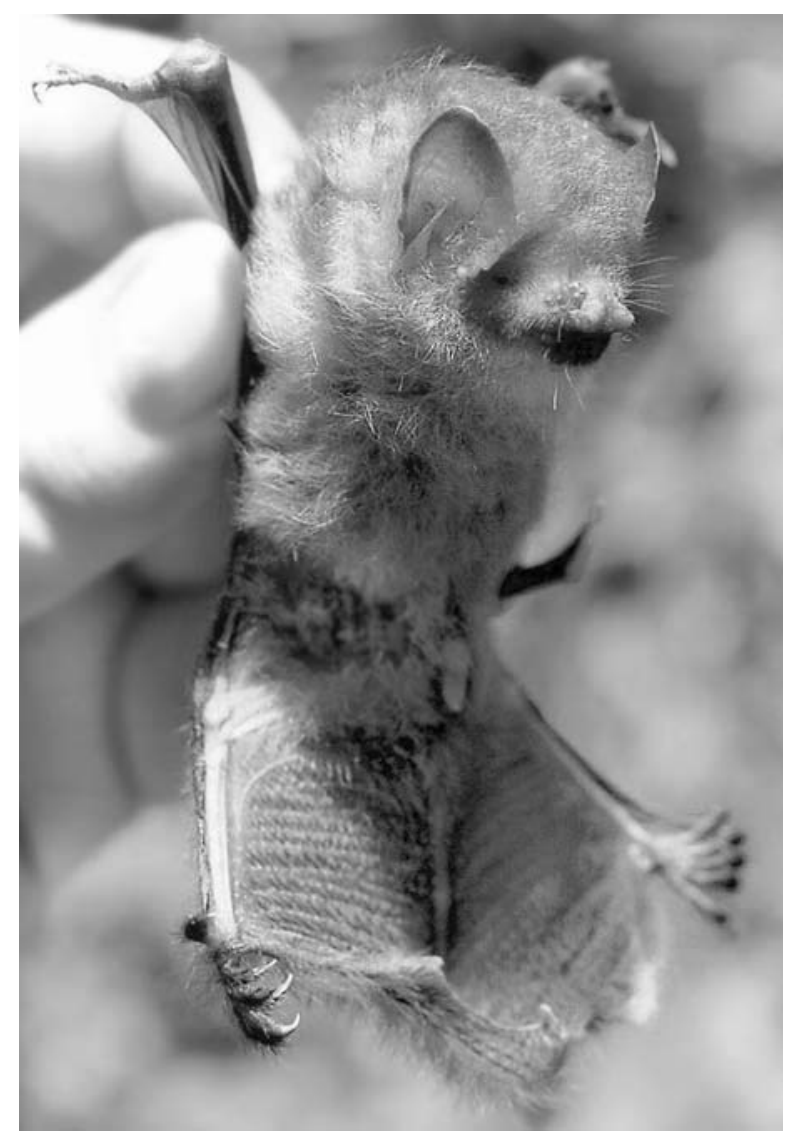

Figure 8. Hairy-winged tube-nosed bat Harpiocephalus harpia, adult male. bent-winged bats are thought to be connected with rock outcrops, possessing internal hollows or deep cavities. Such structures probably could be found on the slope of the Dalat Plateau, east from the Hon Giao Mount, or even on the Plateau itself, where they, however, at least not common. We did not observed bent-winged bats visually during our surveys. Our record of this species is first for the Dalat Plateau and Lam Dong Province.

\section{ORDER RODENTIA}

\section{Family SCIURIDAE}

Tamiops maritimus (Bonhote, 1900)

The maritime striped squirrel occurs at many provinces of Vietnam (Dang Ngoc Can et al., 2008). This diurnal squirrels were commonly observed during our surveys in the Bi Doup - Nui Ba National Park and were recorded in many biotopes up to $2100 \mathrm{~m}$ a.s.l. We collected eight specimens in 2008 and one specimen in 2009 (Fig. 9).

Adler et al. (1999) recorded for the Dalat Plateau (near the Lang Bian Mountain) the Burmese, or Himalayan striped squirrel, Tamiops macclellandii. However this record is probably based on misidentification. The latter species in Vietnam supposed to be restricted to Red River basin in northern part of the country (Lunde \& Nguyen Truong Son, 2001; Dang Huy Huynh et al., 2008; Dang Ngoc Can et al., 2008). Nevertheless necessary to mention that all Vietnamese Tamiops species except for $T$. rodolphei are hardly distinguishable in the field and their individual, geographic and seasonal variation needs further investigation (Lunde \& Nguyen Truong Son, 2001).

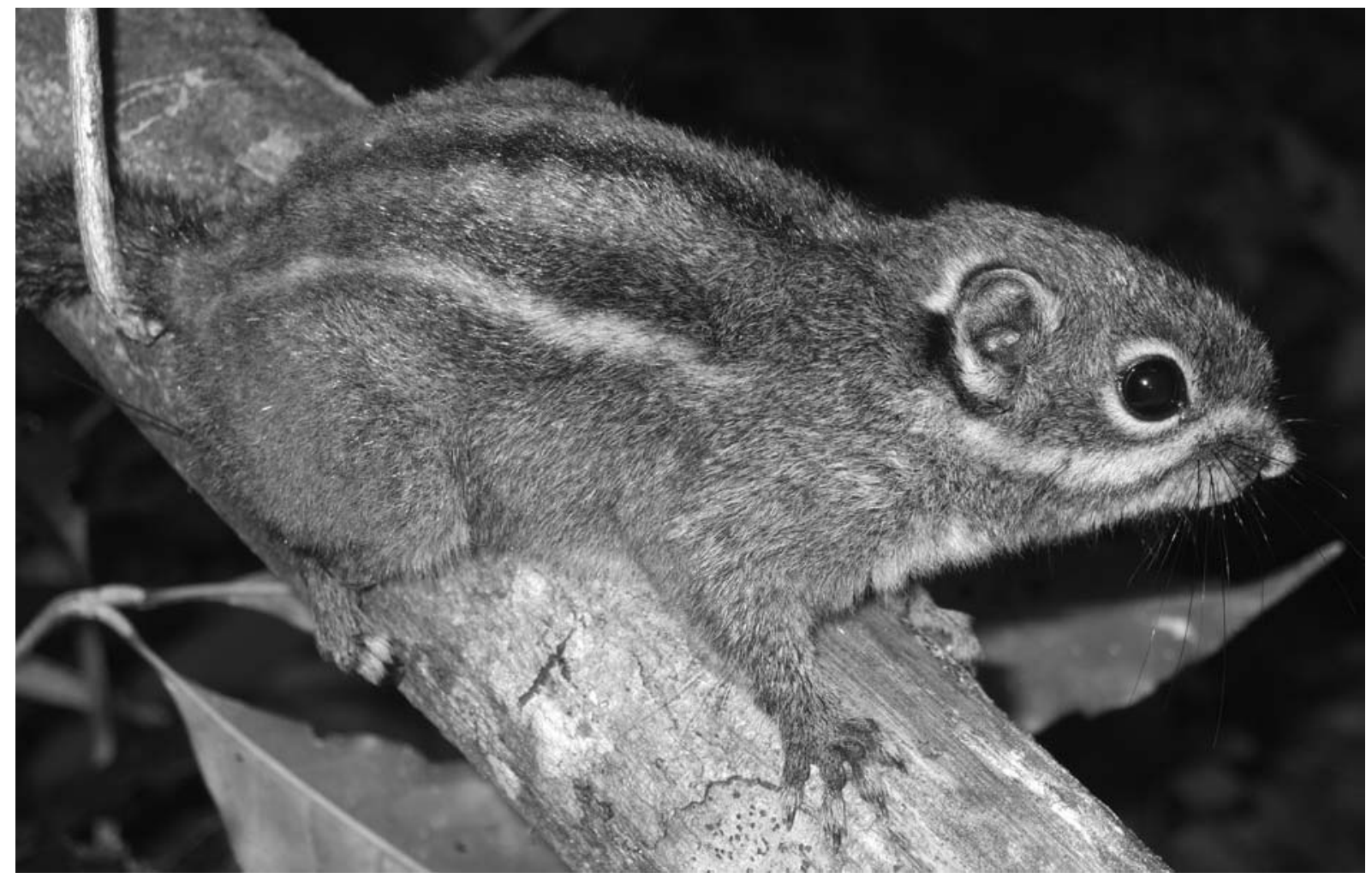

Figure 9. Maritime striped squirrel Tamiops maritimus. 
Callosciurus erythraeus (Pallas, 1779)

The Pallas's squirrel is one of a common species of arboreal mammals in Vietnam widely distributed in the country (Dang Huy Huynh et al., 1994; Dang Ngoc Can et al., 2008). The species was observed in the different biotopes at elevation range from 1200 to $1980 \mathrm{~m}$ a.s.l. (see also Borissenko et al., 2006).

\section{Dremomys rufigenis (Blanford, 1878)}

This species is widespread throughout hill and mountainous areas of Southeast Asia. It recorded everywhere on the Dalat Plateau (Adler et al., 1999; Borissenko et al., 2006; Dang Ngoc Can et al., 2008).

We observed this squirrel twice in the mixed forest near Danim River in 2002.

\section{Ratufa bicolor (Sparrman, 1778)}

The species widely distributed in Vietnam. One specimen was observed at 11 April, 2002 in the primary forest near Danim River. Another one was observed on western slope of the Bi Doup Mountain in April 2002. However during the surveys of 2008-2009 this noticeable species was not seen, which indicate that giant squirrel is at least not common on the discussing territory.

\section{Hylopetes alboniger (Hodgson, 1836)}

The particolored flying squirrel is widely distributed in Southeast Asia. In Vietnam the species found from northern provinces to the Phu Quoc Island in the south (Abramov et al., 2007b; Dang Ngoc Can et al., 2008). The species also recorded from the northern and eastern parts of the Dalat Plateau (Chu Yang Sin National Park and Hon Ba Mount).

Two adult males were captured nearby the base camp, in riverside forest. The flying squirrels were caught by use of the live cage-traps set on the tree brunches at about 10-12 $\mathrm{m}$ above ground, and were released in the same place after examination and measuring.

\section{Petaurista philippensis Elliot, 1839}

The giant flying squirrel is widely distributed in Vietnam (Dang Ngoc Can et al., 2008). One specimen was observed in evening time $\left(20^{30}\right)$ at 30 March, 2008 in the canopy near the base camp. Pair of giant flying squirrels was observed in the same place, moving through the canopies in riverside forest in evening time at 28 April, 2009.

\section{Family MURIDAE}

Mus caroli Bonhote, 1902

The species widely distributed in southern Asia. It occurs in many regions of Vietnam and inhabits fields and other agricultural areas (Lunde \& Nguyen Truong Son, 2001; Dang Ngoc Can et al., 2008).

Three specimens were collected in 2002 and 2008 in grasslands near Danim River. Another one was caught by locals on the corn field near the base camp in 2008 .

Mus pahari Thomas, 1916

The Indochinese shrew-like mouse is widespread in northern and central Vietnam (Dang Huy Huynh et al.,
1994; Lunde \& Nguyen Truong Son, 2001). This is a rather large mouse, of which distinctive features are long-nosed shrew-like head and spiny dorsum.

Four specimens were collected in 2002 (Borissenko et al., 2006). Two adult males were caught in 2009 in the live-traps placed on fallen tree connected two banks of small forest stream, at the elevation of $1400 \mathrm{~m}$ a.s.1. nearby the base camp.

\section{Chiropodomys gliroides (Blyth, 1856)}

The species is widely distributed in Vietnam (Dang Huy Huynh et al., 1994; Dang Ngoc Can et al., 2008).

In 2006, we collected 13 specimens of the Indomalayan pencil-tailed tree mouse. Most of specimens were caught on the same trapping line. The cage traps were set up on woody lianas and tree branches (Manglietia sp., Symplocos sp. and others) approximately at 2-5 m above the ground. We collect only one adult female in this area. Three subadult specimens (two males and one female), possible her offsprings, were trapped in the neighboring traps during next two days. All other penciltailed tree mice collected were adult males. Perhaps this area attracts the mice by a season availability of food. The trees here were densely twined by vines (Smilax, Cissus, Rubus) and epiphytes (Asplenium nidus).

Rattus nitidus (Hodgson, 1845)

The indigenous distribution range of white-footed Indochinese rat is whole mainland Southeast Asia (Musser \& Holden, 1991). In pristine environments, $R$. niti$d u s$ lives in forested habitats along streams (Musser \& Carleton, 2005). The species was recorded in such habitat near the Lang Bian Mountain by Adler et al. (1999). However we found this species in the Bi Doup Nui Ba National Park as the synanthropic dweller only. Two adult males were caught in April 2002 in the house of forest station located in the Long Lanh Village.

Rattus andamanensis (Blyth, 1860)

The Indochinese forest rat is one of typical Rattus species in the different types of Vietnamese forest. This species listed as sikkimensis, remotus or koratensis for the different regions of Vietnam (see Corbet \& Hill, 1993; Musser \& Carleton, 1993; Lunde \& Nguyen Truong Son, 2001; Kuznetsov, 2006). We follow Musser \& Carleton (2005) in including all these names as synonyms of andamanensis.

We collect four adult specimens in 2002. All rats were caught in the riparian biotopes on the small tributaries of Danim River near Long Lanh Village.

Niviventer langbianis (Robinson et Kloss, 1922)

The species was described from the Lang Bian Mountain at the south part of the Dalat Plateau (Robinson \& Kloss, 1922). According to the recent checklists (Lunde \& Nguyen Truong Son, 2001; Dang Ngoc Can et al., 2008) the Indochinese arboreal niviventer is widely distributed in Vietnam.

We collect eight specimens in 2008 at the elevation near $1400 \mathrm{~m}$ a.s.l. in the mixed forest near the base 
camp. All niviventers were caught in the cage-traps set at $1 \mathrm{~m}$ above ground on vines, lianas and trees. The species was not recorded in 2002 and 2009.

Niviventer fulvescens (Gray, 1847)

The Indomalayan niviventer is widely distributed in Vietnam. The common species in the south of the Dalat Plateau (Lang Bian Mountain), where known to occur in all forest biotopes (Adler et al., 1999).

We collect four specimens in 2002 in primary forest at the elevation 1350 and $1800 \mathrm{~m}$ a.s.l. Twenty two specimens were collected in 2008-2009. The Indomalayan niviventers were caught in many traplines located on the ground and tree branches 1-2 $\mathrm{m}$ above ground, at the wide elevation range up to $2050 \mathrm{~m}$ a.s.l.

Some authors have referred to populations occurring in southern Indochina as Niviventer bukit (see Corbet \& Hill, 1992). In some characters (sizes, coloration) the niviventers from Bi Doup are close to bukit. However we follow Musser \& Carleton $(1993,2005)$ in including bukit as a synonym of fulvescens before complete taxonomic revision of fulvescens-bukit species complex (see also Lunde \& Nguyen Truong Son, 2001).

Niviventer tenaster (Thomas, 1916).

The species is widely distributed in Southeast Asia. The species occurs in many provinces of Vietnam from the Chinese border in the north to the Dalat Plateau in south (Dang Ngoc Can et al., 2008).

We collect five specimens in May 2009. All specimens were caught at primary forest in trapping lines set up on ground and 1-2 $\mathrm{m}$ above ground (on the trees and lianas). The species was not recorded in previous surveys $(2002,2008)$.

Maxomys moi (Robinson et Kloss, 1922)

The species was described from the Lang Bian Mountain at the south part of the Dalat Plateau (Robinson \& Kloss, 1922). The Indochinese mountain maxomys recorded only from highlands of South Vietnam in Quang Tri, Quang Nam, and Lam Dong provinces (Van Peenen et al., 1969; Dang Huy Huynh et al., 1994; Dang Ngoc Can et al., 2008) and adjacent southern Laos on Plateau Bolovens.

We collect three specimens in 2008 and two specimens in 2009. All specimens were caught at primary forest.

\section{Leopoldamys edwardsi (Thomas, 1882)}

The species is widely distributed in mountainous areas of northern and central Vietnam (Dang Huy Huynh et al., 1994; Dang Ngoc Can et al., 2008).

One specimen of the giant rat was caught in 2008 in primary forest on the northern slope of the Bi Doup Mountain, at the elevation of $1800 \mathrm{~m}$ a.s.l. Single specimen L. edwardsi collected here in 2002 was misidentified as Berylmys bowersi (Borissenko et al., 2006).

Family SPALACIDAE

Rhizomys sumatrensis (Raffles, 1821)

The Indomalayan bamboo rats are widely distributed in mountainous and hilly areas throughout Southeast
Asia. They occur in bamboo thickets above $1200 \mathrm{~m}$ a.s.l. in southern and central Vietnam (Lunde \& Nguyen Truong Son, 2001; Dang Ngoc Can et al., 2008).

We found the holes of these burrowing rodents on the northern slope of the Bi Doup Mountain, at the elevation of 1600-1700 m a.s.l. One adult specimen was obtained from the locals in 2008.

\section{Family HYSTRICIDAE}

Hystrix brachyura Linnaeus, 1758

The Malayan porcupine is widely distributed in Vietnam (Dang Ngoc Can et al., 2008). One specimen was observed on April 12, 2002 near Danim River at about $3 \mathrm{~km}$ east from the Long Lanh Village. The animal was seen in the bushes on the edge of the mixed forest in the evening hours, about half an hour before sunset. Complete skeleton with the skull of adult porcupine was collected in a snare line set by local hunters in the primary forest on the left bank of Danim River in $200 \mathrm{~m}$ from the base camp in 2008.

\section{Discussion}

The Dalat Plateau supports a high level of mammal diversity. The Bi Doup - Nui Ba National Park also contained a rich small mammal fauna of more than 16 species of murids and sciurids and more than 7 species other non-volant mammals.

The rodent fauna was dominated by Niviventer spp. These species were found in a variety of habitats at the wide elevation range. Niviventer fulvescens was by far the most abundant rat species in the studied area similar to south part of the Dalat Plateau (see Adler et al., 1999). Another forest rats Maxomys moi and Leopoldamys edwardsi were found in primary forest only. We did not found in the Bi Doup - Nui Ba National Park the Berylmys bowersi recorded for the Lang Bian area by Adler et al. (1999). The authors supposed that species may be a gap specialist that also exploits forest edges and grasslands. We did not found the long-tailed climbing mouse Vandeleuria oleracea recorded for Lam Dong Province (Adler et al., 1999; Dang Hyu Huynh, 2008; Dang Ngoc Can et al., 2008). Adler et al. (1999) found this species exclusively in grasslands in the studied area near the Lang Bian Mountain at an elevation of $1700 \mathrm{~m}$ a.s.l. The enigmatic species Rattus osgoodi described from the Lang Bian Mountain Area (Musser \& Newcomb, 1985) known on the type series collected by W.H. Osgood in 1937. This species was not found in north-east part of the Dalat Plateau during our surveys.

The sciurid fauna is typical for the forests of Southern Vietnam. Two arboreal species, Tamiops maritimus and Callosciurus erythraeus, are easily for observations and seems to completely dominate the forest habitats. The terrestrial species, Dremomys rufigenis and Menetes berdmorei also recorded for the Dalat Plateau (see Dang Ngoc Can et al., 2008).

The fauna of insectivorous mammals include three or four shrews, one mole and the short-tailed gymnure Hylomys suillus. The latter species was recorded by 
Adler et al. (2001) for the highlands (1750 m a.s.1.) in the Lang Bian Mountains (see also Dang Ngoc Can et al., 2008). A moderately rich insectivore fauna of the Dalat Plateau is typical for the highlands of Vietnam (see also Abramov et al., 2007a; 2008) contrary to the lowlands and hilly areas.

The bat fauna of the Bi Doup - Nui Ba National Park is not as rich as that of Vietnamese lowlands (e.g. Cat Tien National Park, see Pham Nhat et al., 2001), but consists of at least 13 species from four families.

Species mentioned as most abundant, namely $R h i$ nolophus affinis, Pipistrellus coromandra, Arielulus circumdatus and Scotomanes ornatus, probably occur on the Plateau permanently. We possess direct evidence of $R h$. affinis breading on the Plateau, however it is possible to suppose that three other species also may produce offspring in the investigated area. Capturing of subadults of Pipistrellus coromandra in 2009 indirectly support this supposition. Also breading on the investigated territory directly or indirectly was shown for Myotis muricola, M. phanluongi, Murina harpioloides and for Rhinolophus lepidus, which very probably have sporadic distribution on the Dalat Plateau and do not rich the same abundance as previously mentioned four species. One can suppose that these eight bats form "core" of the local bat fauna in the Bi Doup - Nui Ba National Park, more or less completely representing basic ecological groups of insectivorous bats (Kruskop, 1999). We can mention different aerial hawkers, exploiting variable foraging space, from open air above the clearings (Arielulus circumdatus, Scotomanes ornatus) to highly cluttered space under the forest cover (e.g. Harpiocephalus harpia and Rh. lepidus). Myotis phanluongi, according to observed behavior, can be considered a water surface gleaners; this guild occasionally can be added by vagrant Myotis horsfieldii. Finally, Murina harpioloides is probably foliage or ground gleaner. It seems probable that climate on the elevations above the $1300 \mathrm{~m}$ a.s.1. is too cool and local forests, which are seasonal and per ce subtropical (Dao Van Tien, 1978; Wikramanayake et al., 2001), do not produce enough food sources for fruit bats, thus we did not found any members of Pteropodidae family. Megaderma lyra, the only carnivorous bat represented in Southern Vietnam (Borissenko \& Kruskop, 2003), was not observed during our survey. This species is not know inhabiting elevations above the $925 \mathrm{~m}$ a.s.l. (Bates \& Harrison, 1997).

At least Arielulus, Scotomanes, Rhinolophus lepidus and Myotis phanluongi possess most related congenerics in more north and/or mountainous regions of the Southeast Asia; the same we may provisionally mentioned for Murina harpioloides (J. Eger, pers. comm.). Contrary, Myotis horsfieldii and Miniopterus magnater most probably came to the Dalat Plateau from more southern regions. The occurrence of Myotis muricola represents a complex question, since there is a set of forms of different rank hidden under that name. The typical M. muricola was described from Nepalese Hi- malayas (Gray, 1846) and thus in the context of Vietnam fauna should be treated as northern element; however animals found on the Dalat Plateau are identical to the form common in Vietnamese lowlands such as Cat Tien National Park. Summarizing we can conclude that bat fauna of the Bi Doup - Nui Ba area was formed as a combination of northern ("Himalayan") forms, distributed through the mountainous systems, and actual tropical species came from more low elevations.

Our surveys were a first attempts to inventory small mammals of the Bi Doup - Nui Ba National Park. Many of the recorded species represent new distributional findings for the Dalat Plateau and also for Vietnam. Nevertheless the inventory of small mammals of the Dalat Plateau is far from complete.

ACKNOWLEDGMENTS. We are grateful to the administration of the Bi Doup - Nui Ba National Park for providing the opportunity to carry out the surveys in the Park. Our field studies in Vietnam were possible due to the support of the Joint Vietnam-Russian Tropical Research and Technological Centre. We would like to express our thanks to Dr. Phan Luong, Dr. Nguyen Dung Khoi, Dr. A.N. Kuznetsov, Dr. P.N. Morozov and all expedition members for their great help and scientific expertise during the field works.

\section{References}

Abramov A.V., Rozhnov V.V. \& Morozov P.N. 2007a. Notes on mammals of the Ngoc Linh Nature Reserve (Vietnam, Kon Tum Province) // Russian Journal of Theriology. Vol.5 (for 2006). No.2. P.85-92.

Abramov A.V., Kalinin A.A. \& Morozov P.N. 2007b. Mammal survey on Phu Quoc Island, southern Vietnam // Mammalia. Vol.71. No.1-2. P.40-46.

Abramov A.V., Shchinov A.V. \& Rozhnov V.V. 2008. Study of insectivorous mammals in North Vietnam // Contemporary Problems of Ecology. Vol.1. No.5. P.593-595.

Adler G.H., Mangan S.A. \& Suntsov V. 1999. Richness, abundance, and habitat relations of rodents in the Lang Bian mountains of Southern Viet Nam // Journal of Mammalogy. Vol.80. No.3. P.891-898.

Adler G.H., Suntsova N.I., Suntsov V.V. \& Mangan S.A. 2001. Fleas (Siphonaptera) collected from small mammals in Southern Vietnam in 1997-1998 // Journal of Medical Entomology. Vol.38. No.2. P.210-213.

Bates P.J.J. \& Harrison D.L. 1997. Bats of the Indian Subcontinent. Sevenoaks: Harrison Zoological Museum. 258 p.

Bates P.J.J., Hendrichsen D.K., Walston J.L. \& Hayes B. 1999. The review of mouse-eared bats (Chiroptera: Vespertilionidae: Myotis) from Vietnam with significant new records // Acta Chiropterologica. Vol.1. No.1. P.47-74.

Bonhote J.L. 1907. On a collection of mammals made by Dr. Vassal in Annam // Proceedings of the Zoological Society (London). 1907. P.3-11.

Borissenko A.V. 1999. A mobile trap for bats // Plecotus et al. Vol.2. P.1-10. 
Borissenko A.V., Kruskop S.V. \& Dorokhina E.V. 2001. [Bats (Chiroptera, Mammalia) of Vu Quang Nature Reserve: structure and eco-morphological peculiarities of community] // Korzun L.P. \& Kalyakin M.V. (eds.). [Materials of Zoological and Botanical Studies in $\mathrm{Vu}$ Quang Nature Reserve (Ha Tinh Province, Vietnam)]. Moskva \& Khanoi: Joint Russian-Vietnamese Science and Technological Tropical Centre. P.190-215 [in Russian, with English summary].

Borissenko A.V. \& Kruskop S.V. 2003. Bats of Vietnam and Adjacent Territories. An Identification Manual. Moscow: GEOS. 201 p.

Borissenko A.V., Kruskop S.V. \& Morozov P.N. 2006. [Preliminary inventory of the mammal fauna of the southeastern extremity of the Truong Son mountain range] // Korzun L.P. \& Kalyakin M.V. (eds.). [Materials of Zoological and Botanical Studies in Bi Doup and Hon Ba Mountains, Dalat Plateau, Southern Vietnam]. Moskva \& Khanoi: Joint Russian-Vietnamese Science and Technological Tropical Centre. P.159-194 [in Russian, with English summary].

Borisenko A.V., Kruskop S.V. \& Ivanova N.V. 2009. A new mouse-eared bat (Mammalia: Chiroptera: Vespertilionidae) from Vietnam // Russian Journal of Theriology. Vol.7 (for 2008). No.2. P.57-69.

Corbet G.B. \& Hill J.E. 1992. The Mammals of the Indomalayan Region: A Systematic Review. Oxford: Oxford University Press. 488 p.

Csorba G., Ujhelyi P. \& Thomas N. 2003. Horseshoe Bats of the World. Shropshire: Alana Books. 160 p.

Dang Huy Huynh, Dao Van Tien, Cao Van Sung, Pham Trong Anh \& Hoang Minh Khien. 1994. [Checklist of Mammals in Vietnam]. Hanoi: Publishing House "Science \& Techniques". 168 p. [in Vietnamese].

Dang Huy Huynh, Cao Van Sung, Le Xuan Canh, Pham Trong Anh, Nguyen Xuan Dang, Hoang Minh Khien, Nguyen Minh Tam. 2008. [Fauna of Vietnam. Vol.25. Mammalia: Primates, Carnivora, Artiodactyla, Perissodactyla, Rodentia]. Hanoi: Science and Technics Publishing House. 362 p. [in Vietnamese].

Dang Ngoc Can, Endo H., Nguyen Truong Son, Oshida T., Le Xuan Canh, Dang Huy Phuong, Lunde D.P., Kawada S.-I., Hayashida A., Sasaki M. 2008. [Checklist of Wild Mammal Species of Vietnam]. Hanoi: Institute of Ecology and Biological Resources. 400 p. [in Vietnamese].

Dao Van Tien. 1978. [An experience of zoogeographical regionalization of Vietnam] // Zoologicheskii Zhurnal. T.57. No.4. P.582-586 [in Russian, with English summary].

Elliot D.G. 1909. Descriptions of apparently new species and subspecies of monkeys of the genera Callicebus, Lagothrix, Papio, Pithecus, Cercopithecus, Erythrocebus and Presbytis // Annals and Magazine of Natural History. Ser.8. Vol.4. P.244-274.

Gray J.E. 1846. Catalogue of the Specimens and Drawings of Mammalia and Birds of Nepal and Thibet Presented by B.H. Hodgson, Esq. to the British Museum. London: Trustees of British Museum (Natural History). $156 \mathrm{p}$.

Heaney L.R. \& Timm R.M. 1983. Systematics and distribution of shrews of the genus Crocidura (Mammalia, In- sectivora) in Vietnam // Proceedings of the Biological Society of Washington. Vol.96. No.1. P.115-120.

Hendrichsen D.K., Bates P.J.J., Hayes B.D. \& Walston J.L. 2001. Recent records of bats (Mammalia: Chiroptera) from Vietnam with six species new to the country // Myotis. Vol.39. P.35-122.

Hutterer R. 2005. Order Soricomorpha // Wilson D.E. \& Reeder D.M. (eds.). Mammals Species of the World. A Taxonomic and Geographic Reference. Third edition. Vol.1. Baltimore: Johns Hopkins University Press. P.220311.

Jenkins P.D. 1976. Variation in Eurasian shrews of the genus Crocidura (Insectivora: Soricidae) // Bulletin of the British Museum (Natural History), Zoology. No.30. P.271309.

Jenkins P.D., Abramov A.V., Rozhnov V.V. \& Makarova O.V. 2007. Description of two new species of whitetoothed shrews belonging to the genus Crocidura (Soricomorpha: Soricidae) from the Ngoc Linh Mountain, Vietnam // Zootaxa. No.1589. P.57-68.

Jenkins P.D., Lunde D.P. \& Moncrieff C.B. 2009. Chapter 10. Descriptions of new species of Crocidura (Soricomorpha: Soricidae) from mainland Southeast Asia, with synopses of previously described species and remarks on biogeography // Voss R.S. \& Carleton M.C. (eds.). Systematic mammalogy: contributions in honour of Guy G. Musser. Bulletin of the American Museum of Natural History. No.331. P.356-405.

Jiang X.-L. \& Hoffmann R.S. 2001. A revision of the whitetoothed shrews (Crocidura) of southern China // Journal of Mammalogy. Vol.82. P.1059-1079.

Kalko E.K.V. 1995. Insect pursuit, prey capture and echolocation in pipistrelle bats (Microchiroptera) // Animal Behaviour. Vol.50. P.861-880.

Kruskop S.V. 1999. Ecomorphological diversity of plainnosed bats (Vespertilionidae, Chiroptera) // Folia Theriologica Estonica. Vol.4. P.1-33.

Kruskop S.V. \& Eger J.L. 2008. A new species of tube-nosed bat Murina (Vespertilionidae, Chiroptera) from Vietnam // Acta Chiropterologica. Vol.10. No.2. P.213-220.

Kunz T.H. \& Kurta A. 1990. Capture methods and holding devices // Kunz T.H. (ed.) Ecological and Behavioral Methods for the Study of Bats. Washington \& London: Smithsonian Institution Press. P.1-29.

Kuznetsov G.V. 2006. [Mammals of Vietnam]. Moskva: KMK Scientific Press. 428 p. [in Russian].

Lunde D. \& Nguyen Truong Son. 2001. An Identification Guide to the Rodents of Vietnam. New York: Center for Biodiversity and Conservation, American Museum of Natural History. 80 p.

Lunde D.P., Musser G.G. \& Nguyen Truong Son. 2003. A survey of small mammals from Mt. Tay Con Linh II, Vietnam with the description of a new species of Chodsigoa (Insectivora: Soricidae) // Mammal Study. Vol.28. No.1. P.31-46.

Matveev V.A. 2005. Checklist of Cambodian bats (Chiroptera), with new records and remarks on taxonomy // Russian Journal of Theriology. Vol.4. No.1. P.43-62.

Miller G.S. 1940. A new mole from Annam // Journal of Mammalogy. Vol.21. No.2. P.203-204. 
Musser G.G. \& Carlton M.D. 1993. Family Muridae //Wilson D.E. \& Reeder D.M. (eds.). Mammal Species of the World. A Taxonomic and Geographic Reference. Second edition. Washington: Smithsonian Institution Press. P.501-755.

Musser G.G. \& Carleton M.D. 2005. Superfamily Muroidea // Wilson D.E. \& Reeder D.M. (eds.). Mammal Species of the World. A Taxonomic and Geographic Reference. Third edition. Vol.2. Baltimore: Johns Hopkins University Press. P.894-1531.

Musser G.G. \& Holden M.E. 1991. Sulawesi rodents (Muridae: Murinae): morphological and geographical boundaries of species in the Rattus hoffmanni group and a new species from Pulau Peleng // Griffiths T.A. \& Klingener D. (ed.). Contributions to Mammalogy in Honor of Karl F. Koopman. Bulletin of the American Museum of Natural History. No.206. P.322-413.

Musser G.G. \& Newcomb C. 1985. Definitions of Indochinese Rattus losea and a new species from Vietnam // American Museum Novitates. No.2814. P.1-32.

Pham Nhat, Nguyen Xuan Dang \& Polet G. 2001. Field Guide to the Key Mammal Species of Cat Tien National Park. Hanoi: WWF - Cat Tien National Park Conserva- tion Project, Fauna \& Flora International - Indochina Programme. 145 p.

Robinson H.C. \& Kloss C.B. 1922. New mammals from French Indo-China and Siam // Annals and Magazine of Natural History. Ser.9. Vol.9. P.87-99.

Rozhnov V.V. 1998. [The natural history investigations in Indochina: a retrospective review] // Korzun L.P. \& Kalyakin M.V. (eds.). [Materials of Zoological and Botanical Studies in Fan Si Pan Summit Area (North Vietnam)]. Moskva \& Khanoi: Joint Russian-Vietnamese Science and Technological Tropical Centre. P.11-66 [in Russian, with English summary].

Thomas O. 1909. A new gibbon from Annam // Annals and Magazine of Natural History. Ser.8. Vol.4. P.112-113.

Van Peenen P.F.D., Ryan P.F. \& Light R.H. 1969. Preliminary Identification Manual for Mammals of South Vietnam. Washington: Smithsonian Institution Press. 310 p.

Wilson D.E. \& Reeder D.M. (eds.). 2005. Mammal Species of the World. A Taxonomic and Geographic Reference. Third edition. Vols.1-2. Baltimore: Johns Hopkins University Press. 2142 p.

Wikramanayake E., Dinerstein E. \& Loucks C. 2001. Terrestrial Ecoregions of the Indo-Pacific: A conservation Assessment. Washington DC: Island Press. 824 p. 